\title{
Styles and logics of territorial action. The recent experience of the municipalities of Paraguay
}

\section{Marcelo Sili 12}

${ }^{1}$ Consejo Nacional de Investigaciones Científicas y Técnicas (CONICET), Buenos Aires - Argentina

2 Universidad Nacional del Sur / Departamento de Geografía y Turismo, Centro ADETER, Bahía Blanca - Argentina

Territorial action is a complex process of development in which public, private, and collective actions intervene. As the Latin American experience shows, municipalities are increasingly important actors in building local development. They act in different ways, and this work highlights these differences in style and form of intervention. The study identifies four types or styles of action that synthesize two main elements. First, the forms of organization for obtaining resources. Second, the types of actions prioritized to build development processes and reduce problems of structural poverty.

Keywords: territorial action; municipalities; territorial development; Paraguay.

\section{Estilos y lógicas de acción territorial. La experiencia reciente de los municipios del Paraguay}

La acción territorial es un complejo proceso de construcción del desarrollo en el cual intervienen la acción pública, la privada y la colectiva. Como lo demuestra la experiencia latinoamericana, los municipios son actores de creciente importancia en la dinámica de construcción del desarrollo local. Sin embargo las formas de actuación de los municipios no son iguales. Al contrario, este trabajo muestra profundas diferencias de estilos y formas de intervención entre todos ellos. Pudimos identificar cuatro tipos o estilos de acción que sintetizan dos grandes elementos. En primer lugar, las formas de organización para la obtención de recursos y, en segundo, los tipos de acciones priorizadas para construir procesos de desarrollo y para reducir problemas de pobreza estructural. Palabras clave: acción territorial; municipios; desarrollo territorial;

\section{Estilos e lógicas de ação territorial. A experiência recente dos Municípios do Paraguai}

A ação territorial é um processo complexo de construção de desenvolvimento em que intervêm a ação pública, a ação privada e a ação coletiva. Como mostra a experiência latino-americana, os municípios são atores de crescente importância na dinâmica de construção do desenvolvimento local. No entanto, as formas de ação dos municípios não são as mesmas. Pelo contrário, este trabalho mostra diferenças profundas em estilos e formas de intervenção entre todos eles. Fomos capazes de identificar quatro tipos ou estilos de ação, que sintetizam dois grandes elementos. Em primeiro lugar, as formas de organização para obter recursos e, segundo, os tipos de ações priorizadas para construir processos de desenvolvimento e reduzir os problemas de pobreza estrutural.

Palavras-chave: ação territorial; municípios; desenvolvimento territorial; Paraguai. project executed by the "Investigación para el Desarrollo del Paraguay (Investigation for the Development of Paraguay), financed by the International Development Research Center and the CONACYT (The National Council of Science and Technology), through the PROFICIENCIA Program, with resources from the Fund for Excellence in Education and Research - the FEEI of the FONACIDE (The National Fund for Public Investment and Development). 


\section{INTRODUCTION: NEW MUNICIPALITIES, NEW TERRITORIES}

The historical Paraguayan territorial model has been structured around a few cities linked to the public and commercial sphere, with a small population and surrounded by rural areas where most of the population resided. These areas were dominated by family farms, with hundreds of small towns and settlements which would historically complement the cattle farms and the workshops. This territorial model has changed in the past decades, becoming more complex and being characterized by several concomitant factors, amongst which is the growing weight of cities of all sizes with emerging industries and a firm decentralization process of urban services, especially the financial, educational, and wholesale businesses ones (Vázquez, 2013). Thusly, it can be stated that Paraguay is living through a unique transformation, going from a territorial model characterized by little spatial movement, development of the farming economy, minor exploitation of resources, and an endogenous outlook, towards a more open model, with strong spatial mobility, decentralization, and linked to the export of energy and farming products (Verdecchia, 2007).

Thus, the Capital and the "Interior" (department capitals and their rural surroundings) had had a hierarchical and centralizing function, with their historical centers (plaza, church, police, commerce, and government) which ruled over the integrated neighborhoods. Today, the scheme is a network of agglomerations. An example would be the metropolitan region of Asuncion which had been formed by the capital city and its neighboring cities. Nowadays the Central department is growing, but the capital isn't, even though it maintains its position of leadership, and a network of cities replaces the downtown and its surrounding areas. This is also happening to the nodes and the methods of transportation. The traditional North-South axis, from the capitals towards the south, has become more complex. The North-South fluvial node or axis towards the Rio de la Plata remains strong, specially for exporting. However, there are also other axes of growing importance: the EastWest between Asuncion-Ciudad del Este, another East-West parallel between Concepcion and Pedro Juan Caballero, and the other North-South axis with intermediary cities in the center of the Eastern Region, etc. (Vázquez \& Goetz, 2013).

On the other hand, the rural territories have become more complex. Family farms persists, but with non-traditional patterns, modified by the new communications technology and by access to cheap personal transport; prosperous fruti-horticultural family farm economy which supplies the cities is consolidating in many zones. In the same manner, a dynamic and international corporate agriculture is being formed, with strong international positioning (Paraguay has been since 2012 the sixth producer and fourth exporter of soy worldwide, as well as the ninth exporter of beef, both accounting for $65 \%$ of its exports and $25 \%$ of its GDP), positioning which has been led by a significant group of multinational companies such as Cargill, ADM, Bungue Paraguay S.A., Monsanto, Agrotec S.A., and Luis Dreyfus Paraguay S.A., which became major players in the local territorial sphere (Cámara Paraguaya de Exportadores y Comercializadores de Cereales y Oleaginosas [CAPECO], 2013; Guereña, 2011; Programa de las Naciones Unidas para el Desarrollo [PNUD], 2010; Riquelme \& Vera, 2013; Rojas, 2009; Ruiz, 2008).

A strong tension between the multiple players and their array of projects for the future can be seen within this territorial transformation dynamics. For example, certain sectors strive to control territories, 
increase competition, and develop export economies: silos, industries, ports and barges to transport grains. Other sectors strive to maintain their territories and social groups as to not be displaced. These territorial control dynamics show different ways of understanding and interpreting territory and development; for some they are synonyms of space for production, growth, and accumulation, while for others they are synonyms of quality of life and settlement. The aboriginal social groups, which have recently been assimilated to the Nation State and who, despite being a minority, have their own ethnic and territorial claims, are added to the latter.

As a result, the emergence of numerous initiatives such as plans, programs, and projects for development of all kinds can be observed in the country. These show and reflect multiple objectives, such as those of overcoming the crisis processes of those territories not benefitted by the economic growth dynamics or who do not sort out the competition, or those of attracting new economic and productive opportunities in the more dynamic territories, thus trying to consolidate bigger growth scenes with a favorable state governance and the consolidation of the insertion of the local agroindustry in internationally valued chains. This multitude of initiatives come from the Central Government, the Governances and the municipalities, and from the private sector (companies, producers, etc.) and social organizations, who are each time drawing more and more attention. It's noteworthy that many times these initiatives are marked by overlapping, conflict, and competition amongst them which in many occasions lead to a loss of efficiency and of their impact or to a gameplay of negatives where nobody wins.

Municipalities are gaining an ever more important role within this new context of territorial transformations and multiple initiatives for development. Furthermore, as in most of the Latin American countries, the municipalities in Paraguay have become key players in the development of their regions (Aghón \& Cortes, 1998; Nickson, 2016; Victory, 1999). They went from being preoccupied by the maintenance of their urban layout, the upkeep of their streets, and garbage collection, to being organisms responsible for the promotion and development of their whole territory which includes urban settlements and the rural areas with a spread-out population. However, all municipalities do not act in the same manner; on the contrary, there is a great diversity of styles which depend on the vision they have on development, on territorial conditions, models of governance and coordination of players, and of the resources they posses which tend to be limited. The combination of these factors define different management styles or of territorial action which end up strengthening or inhibiting development dynamics.

From an analytical point of view and aiming to strengthening the territorial development processes at a municipal level, this work's objectives is not to perform a diagnostic regarding the functioning of the municipalities in Paraguay, but rather to describe and analyze the style of intervention of the Municipalities around their territories' problems and the construction of their development dynamics. A thorough comprehension of these styles would allow to define the best policies for institutional strengthening at a municipal level, thus strengthening development opportunities in the country.

Considering this objective, the hypothesis which supports this research is that there are in Paraguay municipalities with diverse and heterogenous territorial action which, besides accounting 
for the specific forms of intervention in the construction of development and reduction of poverty, reveal other two key elements. First concerning the structural conditions of the territory, which is to say that every kind of territorial action style indicates a type of problem in the territory, of their production systems, and their social realities. Second, every one of these styles of territorial actions reveal the representations which underlie the mentalities of the mayors and of their governance teams concerning the development of their own territories, which is to say that these styles of territorial action are a manifestation of what those players believe should and can be done concerning territorial development.

\section{CONCEPTUAL FRAMEWORK OF TERRITORIAL ACTION}

The analysis of the municipalities' territorial action styles and the validation of this work hypothesis is performed by using the concept of "territorial action" as a conceptual framework of reference, it being understood as

"[...] the set of initiatives and actions set in motion by the different players involved in a territory capable of providing such territory with purpose, meaning and guidance, generating functionalities and legitimizing infrastructure locations, productive systems or normative orders deployed in the territory, classifying it in function of its own sense of present and future in function of the ideals of development the players committed to the territory have" (Bustos Cara, 2008, p. 6).

In other words, territorial action is the process through which a society builds its territorial action associated with its development ideals.

Territorial action is necessarily a complex process which integrates the past, considering the memory and inherited physical structures, the present, due to the current contextual conditions, and the future, according to the images and representations had concerning the expectations and desired endeavors which determine intent when taking action. In this manner, territorial action necessarily integrates and coordinates multiple and diverse timely initiatives by the players with very different life rhythms since not all players and social groups involved necessarily follow the same logic and cultural rhythms, hence territorial action being also a clear generator of conflict among players and social groups since the actions by one party clash or limit those of the others. Territorial actions are not always horizontal no Benefit every player or inhabitant of a territory; on the contrary, it may be actions which contradict the development ideas and representations of other players.

The strategies to overcome the conflicts generated by the territorial actions of multiple players is not a task for which there are clear guidelines, but rather a task of political and technical scope (Sili, 2018). Thus, such as the De Rubertis plantea (2010)

"Therefore, it is necessary to identify the institutional mechanisms that each community has selected and organised in managing conflicts, in order to assess how much the planning processes put in 
place are based and effective on the principles of participatory democracy and how much they are, instead, conditioned by the existing power relations between the subjects and the groups that are confronted" (De Rubertis, 2010, p. 10).

In this manner, territorial action must not only be understood through a perspective of construction and transformation of the society and the territory, as something to be done in the territory contained by a conditioning structure (physical medium, institutional political conditions, etc.), but also as something with leeway and autonomy for the subjects which allows for thought and to promote an optimistic vision concerning the possibility of intervention and construction of desired scenes. Territorial action is thus incarnated as a subject with intent, aimed at the future, a competent subject with the capability of mobilizing resources, knowledge and information concerning reality. This assumes acknowledgement that "not only does the player not exist outside of a system which defines his liberty and the reason he can use in his actions, but also that the territory (system) does not exist without the player who gives it life and can transform it" (Crozier \& Friedberg, 1977, p. 11)

The adoption of the strategic approach proper to the sociology of organizations is clearly based on the need to understand the logic and forms of action of the multiple actors involved in the territory, which includes, as noted above, cooperation and conflicts as the raw material for negotiation processes. Thus, as stated by Truda (2008)

"The Economic and social development always results a combination between different factors and actors. In a contest of territorial governance, originate the necessity of cooperation between the actors and the ability to adquire knowledges and competences. To know a territory require the collaboration of expert and actors and when the scientific aspect reconcile itself with the concrete aspect of the structure can act on a concrete problem of the territory" (Truda, 2008, p. 339).

On the basis of this recognition of the strategic game of the actors, but with a view to the construction of territories of the future, Oosterbeek (2014) raises the need to build a more pragmatic and constructive conception for territorial development, through what it calls "Integrated Territorial Management", by which the construction of actions for territorial development

"They were based on the understanding that knowledge (of the environment, technology and social processes) and logistics are the basis of a process that must look to the future, facing the dilemmas of choice that are offered, at each moment, to society, which in turn favors the definition of convergent medium and long-term visions, and also governance" (Oosterbeek, 2014, p. 188).

In summary, territorial action constitutes a group of initiatives which the players set in motion to construct and give sense to a territory. These initiatives are placed in a given space of interaction (action territory) included within a broader structuring context (territories and societies which 
encompass and contain them) and are structured under a model of governance; they are conditioned by standing formal or informal norms or rules and the exchange of resources which are characterized by being scarce and unevenly distributed (Manzanal \& Ponce, 2012).

The territorial action generated by the municipalities is analyzed through this research from this conceptual perspective; that is actions carried out to build the development of their territories under the assumption that these territorial actions structure the future. However, it must be made clear that not the whole group of territorial action taking place in the municipalities and districts will be analyzed in this work since this also involves other multiple players, such as the private sector (companies, agricultural producers, artisans, etc.) and collective players (social organizations, productive organizations, etc.) which do not constitute the object of analysis of this research.

\section{STAGES OF RESEARCH AND ANALYSIS}

The analysis and validation of the proposed hypothesis was carried out in three stages from the methodological point of view.

First, a national survey was carried out among the mayors and municipal governance teams in 250 municipalities nationwide. This survey revealed information on the general characteristics of the municipalities, the mayors, the style of management and the actions set in place by the municipalities in their territories. All this information was processes using a statistics software and a Geographical Information system which allowed to generate different types of tables, graphs, and maps. The following key questions appear within this survey:

- Question 6: Main problems of the Municipalities.

- Question 14: Main initiatives carried out to generate development dynamics.

- Question 16: Main actions carried out in the District to reduce poverty).

These questions, which constitute the three main variables of analysis, gave rise to multiple responses that were organized into 8 categories in order to facilitate processing.

Second, based on this information a classifying analysis was carried out with the objective of identifying the different styles of territorial action, for which two key variables were used: firstly, the type of initiatives carried out by the Municipality to promote development and secondly the initiatives used specifically to reduce poverty. This is justified because the main problem mentioned by the municipalities was poverty, which was ratified by the available figures of the Unsatisfied Basic Needs. The classification and creation of typology was done through the Ward method in order to achieve levels with columns as homogenous as possible among them, and as heterogenous as possible in relation to the others.

Third, and with the typology of the municipalities already established, 20 interviews were carried out with the mayors of municipalities representative of each category based on a predetermined script to be able to carry out an in-depth analysis and characterization of each of them. These interviews were carried out taking into account the "strategic analysis" methodology inspired in 
Crozier and Friedberg (1997) which allowed to understand the relation established between the system (territorial context which defines the liberty of the player, as well as the reason employed in his action) and the player himself (the municipality) generating the actions. Therefore, as set by Crozier y Friedberg

"forced to recognize and assume the irreducible contingency of the phenomenon that it seeks to study, strategic analysis must adopt an inductive hypothesis approach... a procedure served by the lived experience of the participants to propose and verify the ever more generalized hypothesis on the characteristics of the organization" (Crozier \& Friedberg, 1977, p. 369-370).

Under this theoretical framework methodology, it can be understood that the Municipality carries out rational behaviors, but this rationality is a constant game in which the resources controlled by the municipality are present (economic, human and symbolic resources) and the pressures of the system are expressed not only in the growing social demands, but also in the increase of responsibilities derived from the decentralization processes of the past decades.

\section{THE MUNICIPALITY, FUNDAMENTAL TERRITORIAL ORGANIZATION UNIT}

Paraguay is a medium sized country with a surface of $406.752 \mathrm{kms}^{2}$ located in a transition area and with a strategic position in South America. From the point of view of its politic administrative organization, the territory is divided in the capital (Asuncion) and 17 Departments, which in turn are divided in 254 Districts or Municipalities, some of them created recently. These are the fundamental units for territorial organization since they have an administration of their own (The Municipality) which covers an urban area and a rural one. In many cases the urban area is again divided in localities and neighborhoods, while the rural areas are divided in small settlements called "colonias" or "compañias" (figure 1).

The country's geographical characteristics and the settlement and territorial organization historical model have defined Municipalities differing greatly in terms of population and surface, which further complicates the territorial management of the country. In Paraguay there are rural Municipalities smaller than $10 \mathrm{~km}^{2}$ and others, in the Western Region or Chaco, of over 50,000 $\mathrm{km}^{2}$. The following Table 1 shows these profound differences in terms of surface and population among the Municipalities. 


\section{FIGURE $1 \quad$ DEPARTMENTS AND MUNICIPALITIES OF PARAGUAY}

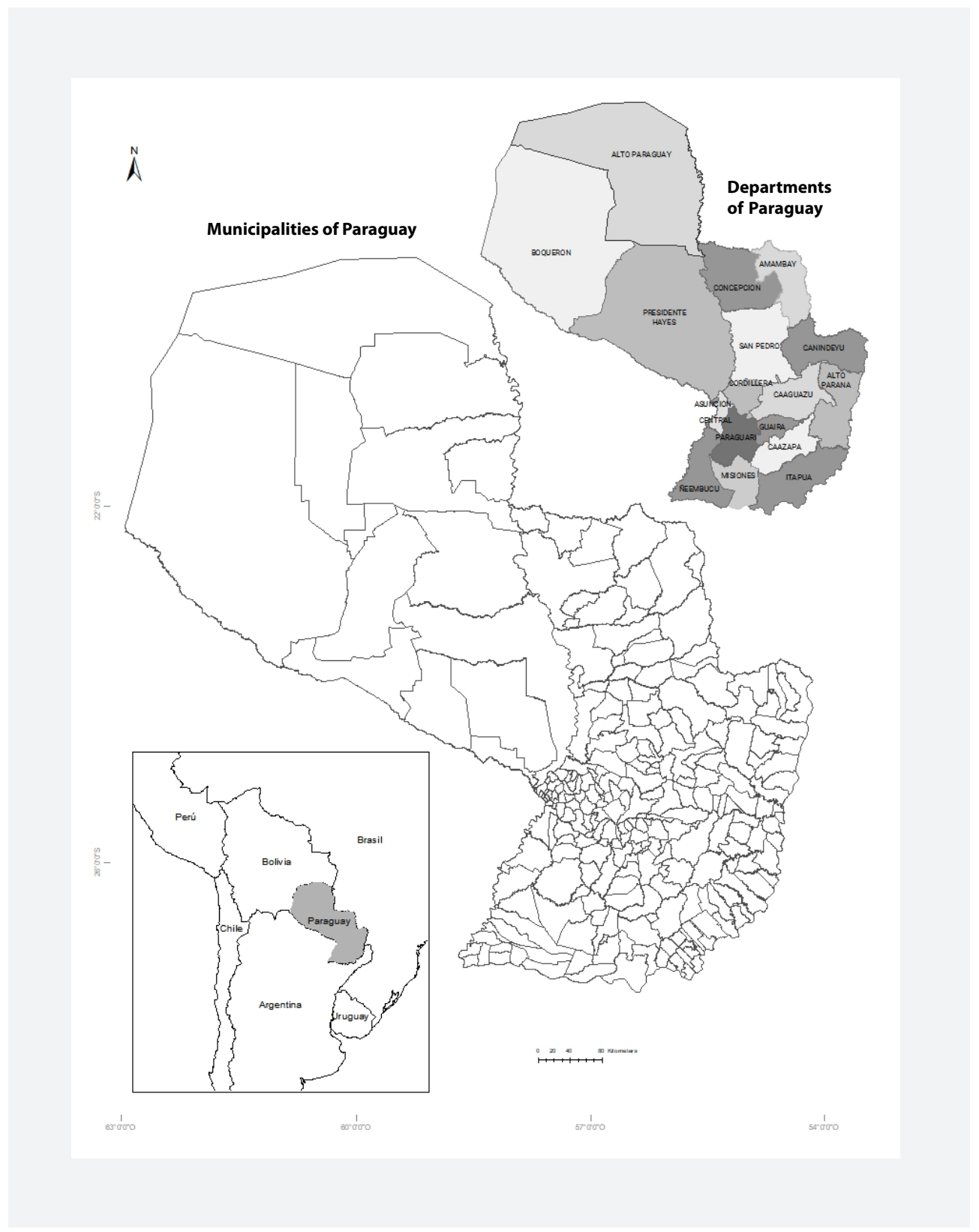

Source: Elaborated by the author based on the official map of the Directorate of the Military Geographic Service of Paraguay. 
TABLE 1

POPULATION LEVELS OF THE MUNICIPALITIES OF PARAGUAY

\begin{tabular}{|c|c|c|c|c|c|c|c|}
\hline Population groups & $\begin{array}{c}\text { Number of } \\
\text { Municipalities }\end{array}$ & Inhabitants & $\begin{array}{c}\% \text { of } \\
\text { inhabitants }\end{array}$ & $\begin{array}{c}\text { Surface } \\
\text { (Km2) }\end{array}$ & $\%$ surface & I/S & POPULATION MEAN \\
\hline $1^{\circ}$ Over de 300.000 & 1 & 525.294 & 7,7 & 128 & 0,03 & 4.104 & 525.294 \\
\hline $\begin{array}{l}2^{0} 100.001 \text { to } \\
300.000\end{array}$ & 13 & 2.210 .951 & 32,3 & 7.573 & 1,9 & 292 & 170.073 \\
\hline $3^{\circ} 50.001$ to 100.000 & 16 & 1.112 .361 & 16,2 & 9.625 & 2,4 & 116 & 69.523 \\
\hline $4^{0} 20.001$ to 50.000 & 50 & 1.479 .908 & 21,6 & 145.171 & 35,7 & 10 & 29.598 \\
\hline $5^{\circ} 10.001$ to 20.000 & 61 & 882.742 & 12,9 & 70.755 & 17,4 & 12 & 14.471 \\
\hline $6^{\circ}$ Up to 10.000 & 109 & 643.270 & 9,4 & 166.740 & 41,0 & 4 & 5.902 \\
\hline Miscalculation & & & & 6.760 & 1,7 & & \\
\hline Total & 250 & 6.854 .526 & 100 & 406.752 & 100,0 & 17 & 27.418 \\
\hline
\end{tabular}

Source: Elaborated by the author based on the Dirección General de Estadísticas, Encuestas y Censos (DGEEC, 2015).

According to the data in the table above, $40 \%$ of the country's territory is occupied by Municipalities which posses only $9.4 \%$ of the population. As a stark contrast, $40 \%$ of the country's population occupies less than $2 \%$ of the country's surface. From a demographical point of view, Asuncion, with its half a million inhabitants, constitutes a singular case; it possesses $7.7 \%$ of the country's population. The second group, made up of 13 municipalities, has a population ranging from 100 thousand to 300 thousand (170,000 average) which accounts for $32.2 \%$ of the country's population. The following 160 municipalities, with a population of 50 to 100 thousand (69,523 average), accounts for $16.2 \%$ of the population. The following 50 municipalities, with 20 to 50 thousand inhabitants (29,598 average) accounts for $21.6 \%$. The last two groups in size range from 10 thousand to 20 thousand $(14,471$ in average) and the last group of under 10 thousand (5,902 in average) account for the remaining 22.3\% of the population.

The municipal governances are in charge of managing the municipality, and its structure is defined by the National Constitution, by the Municipal Organic Law (3,966/2010). Municipal autonomy is guaranteed by the Constitution of 1992 which grants the district's population the right to appoint its authorities and the municipal governance the right to collect taxes: real estate, urban and rural taxes, plus all legally pertinent costs and contributions, which is to say that they have autonomy of the collection and use of their own resources, as well as those resources transferred by the Nation and Departmental Governance. 
The elected positions at the Municipality are Mayor and the Councilors who make up the Municipal Board. In Paraguay, 89\% of mayors are male (223) with only 27 female mayors. Concerning age, mayors mostly range between 41 and 50 years of age (34.4\%), followed by 31 to 40 years of age (31.6\%) and finally 51 to 60 years of age (21.6\%). Concerning education, $4.4 \%$ of the municipalities have mayors who finished primary school, $35.9 \%$ have mayors who finished secondary school, $14.4 \%$ have mayors who finished post-secondary education, and $45 \%$ have mayors who graduated from university.

As to achieve its goals and promote citizen participation, municipal authorities organize other forms of political groups foreseen by the law such as Neighborhood Councils and Neighborhood Associations which represent neighborhoods and promote citizen participation. They also have the Municipal Violations Court appointed by the Municipal Board in order to apply sanctions.

\section{TERRITORIAL PROBLEMS AND MUNICIPAL ACTION}

The problems faced by the Districts in the vast Paraguayan geography are quite disparate and depend on structural issues, clearly pointed out in numerous territorial, social and economic diagnoses of the country and which are linked to environmental conditions, to the lack of infrastructures, to the absence of capital and productive investment, to the heterogeneity of the production systems, to poverty, to the deterioration of the habitat and the constructed space, etc. (Cabello y \& Vázquez Aranda, 2013; Giménez, 2010). However, as it was stated before, the purpose is not to simply understand these "objective" problems, but also the perception and representation that the mayors and their municipal governance teams have on their own reality since policies and development actions are built based on these representations. As stated by

Crozier y Friedberg (1977, p. 377).

"The attitudes of individuals allow us to perceive their values" Attitude constitutes the bridge between the observable behavior of individuals on the one hand (actions) and the structure of values which guide them, which are unseen, on the other. It is through the player's attitudes (in our case the mayors) that their goals are revealed. In the strategic analysis, the state of a system of action and the way in which its characteristics and regulation method structure the games in which the players must engage are what explain the attitudes and what they desire to achieve through them" (Crozier \& Friedberg, 1977, p. 384).

Taking into account this methodology premise, the most important problems as perceived by the mayors are poverty, unemployment, and social isolation, with the lack of roads being second (Table 2). Over $60 \%$ of the mayors place these two issues as the most problematic for the nation's municipalities. In third place they mentioned the lack of and the deterioration of equipment and public services. These three issues account for $76 \%$ of the problems perceived by the municipal mayors. 


\section{TABLE $2 \quad$ THE MAIN MUNICIPAL PROBLEMS PERCEIVED BY THEIR MAYORS}

\begin{tabular}{|c|c|c|}
\hline Problem & Frequency & $(\%)$ \\
\hline Total & 250 & 100,0 \\
\hline Poverty, unemployment, social isolation & 78 & 31,2 \\
\hline Roads & 77 & 30,8 \\
\hline Lack of and deterioration of equipment and public services & 35 & 14,0 \\
\hline Habitat and environmental degradation & 18 & 7,2 \\
\hline Scarcity of basic infrastructure & 14 & 5,6 \\
\hline Institutional weakness of the Municipalities & 12 & 4,8 \\
\hline Violence and Insecurity & 10 & 4,0 \\
\hline Others ${ }^{1 /}$ & 6 & 2,4 \\
\hline
\end{tabular}

Source: Elaborated by the author based on the Local Development Management Survey (2016).

${ }^{1 /}$ Includes: Low development of family farms, does not have problems in their community.

Other problems mentioned by the mayors are the habitat and environmental degradation, the scarcity of basic infrastructure (water, sewage), institutional weakness of the municipalities, and violence and insecurity, specially in the larger Municipalities. It's clear that the problems identified by the mayors and their technical teams are not imaginary problems but perceived from a structural reality which has data and indicators which sustain the perception.

Starting from the identification of local problems from the mayors' perspective, actions are set in motion in order to overcome them (Table 3). According to the national survey, there is quite a vast group of actions which have been regrouped in larger categories. The main initiative carried out by the Municipalities is the improvement or roads and transport systems in general. In second place, it's promoting productive investment and development. Finally, in third place, it's the politic-institutional management as a mechanism to obtain resources, of towards the organization of the local community. These first three topics comprise $71 \%$ of their management. In fourth place are the planning and management of the territory and the environment, the creation and improvement of equipment and public services, and the strengthening of social participation and community life. 


\section{TABLE 3 MAIN ACTIONS CARRIED OUT BY THE MUNICIPALITIES}

$\begin{array}{lcc}\text { Initiatives } & \text { Frequency } & \text { (\%) } \\ \text { Total } & 250 & 100,0 \\ \text { Improvement of roads and transport systems } & 78 & 31,2 \\ \text { Promoting productive investment and development } & 68 & 27,2 \\ \text { Politic-institutional management } & 31 & 12,4 \\ \text { Planning and management of territory and environment } & 21 & 8,4 \\ \text { Creation and improvement of equipment and public services } & 20 & 8,0 \\ \text { Strengthening of social participation and community life } & 14 & 5,6 \\ \text { Others }{ }^{1 /} & & 11 \\ \text { Not Available } & & 7,4\end{array}$

Source: Elaborated by the author based on the Local Development Management Survey (2016).

${ }^{1 /}$ Includes: Citizen assistance, creation of infrastructure.

Beyond the problems perceived by the mayors and of the actions carried out to resolve them, another complementary analysis identified the actions carried out by the municipalities to reduce poverty. In effect, poverty is a multidimensional problem which affects every municipality of Paraguay to a greater or lesser degree, but how the municipalities respond to this issue is quite uneven and depends on the outlook that mayors have regarding poverty and their criteria and ideological postures concerning how to fight it.

Paraguay (and its government officials) has slowly changed its view of poverty from a view centred on income, from a view that is relatively easy to quantify and analyse, to a much more multidimensional conception of poverty, which considers that the causes of poverty are not only lack of income, but also lack of roads (a very important problem in the rural areas of Paraguay, where weather conditions limit connectivity and therefore the population's access to multiple services), accessibility to educational and health services, and access to other personal goods. This multidimensionality of poverty is currently measured through the Multidimensional Poverty Index (MPI) which includes a set of 10 indicators organized into three broad categories: education (years of schooling, children in school), health (infant mortality, nutrition) and standard of living (availability of electricity, sanitation, drinking water, soil, household fuel and miscellaneous goods). According to data from the Human Development Report of UNDP (United Nations Development Programme) and OPHI (Oxford Poverty \& Human Development Initiative) Paraguay has a Multidimensional Poverty Index of 0.064 , being ranked $44^{\text {th }}$ out of 104 countries (from the 1 st least poor to the $104^{\text {th }}$ 
poorest), ranking $15^{\text {th }}$ in the Latin American context, out of a total of 32 countries, i.e. an average situation within the continent

As presented in Table 4, most of the municipalities understands that overcoming poverty is achieved through an improvement of the agricultural production, whether it's for self-consumption or to sell in the market. To achieve this, first the municipality hands out seeds, carries out the tilling of the producers' land lots, etc. Second, poverty is attempted to be reduced through management with the Central Government to give to the population access to national social programs, specially Tekoporâ (social program implemented by the Office of Social Action aimed at the protection and promotion of poor and vulnerable families). In third place, many municipalities consider citizen assistance a way to reduce poverty. This implies handing out construction material, helping on specific health issues, or handing out foodstuff, all of which are elements belonging assistance politics. The initiatives which theoretically appear as promoters of human development or as more structural, which are training, provision of basic services, housing and improving roads, appear with no more than $23 \%$.

\section{TABLE $4 \quad$ MAIN ACTIONS UNDERTAKEN BY THE MUNICIPALITIES TO COMBAT POVERTY}

\begin{tabular}{|c|c|c|}
\hline Actions to combat poverty & Frequency & $(\%)$ \\
\hline Total & 250 & 100,0 \\
\hline Support to agricultural production & 65 & 26,0 \\
\hline Access to Tekoporâ and other social programs & 63 & 25,2 \\
\hline Citizen assistance (handing out materials, money, or other means of direct support) & 37 & 14,8 \\
\hline Others ${ }^{1 /}$ & 29 & 11,6 \\
\hline Training & 18 & 7,2 \\
\hline Provision of basic services & 15 & 6,0 \\
\hline Housing and Access to land lots & 12 & 4,8 \\
\hline Improvement of roads & 11 & 4,4 \\
\hline
\end{tabular}

Source: Elaborated by the author based on the Local Development Management Survey (2016).

${ }^{1 /}$ Includes: Strengthening of Citizen participation, health assistance. 


\section{TYPES, STYLES, AND LOGIC OF TERRITORIAL ACTION}

The combination of actions set in motion to promote development and to reduce poverty defines the styles and logic of territorial actions from the municipalities. For example, local governments who focus their actions on creating infrastructures are not the same as those who center their actions in social assistance, or as those who focus on promoting productive development. Taking this premise into account, a typology of the municipalities and their logic and model of territorial action was built based on this research using the Hierarchical Cluster Analysis methodology. This methodology allows to group observations of a base (in this cast districts) into clusters or relatively homogenous groups based on the chosen characteristics (target variables). To do this, the variables to be used in the analysis were selected, namely, two variables:

- Main initiatives carried out in the District to generate development dynamics, and

- Actions carried out in the District to reduce poverty.

These two large variables were posed as questions in the national survey and gave several possible answers. It is these variables with their possible answers or declines that constitute the object of analysis of this work. Future research should allow crossing these variables with others such as the level of training of mayors, the level of poverty of the Municipality, the number of inhabitants, etc., generating new findings and knowledge of critical importance for the design of development policies.

Once determined, the variables are placed in a reduced matrix of variables $x$ the 250 municipalities of Paraguay. Then, the hierarchical conglomeration method is applied, for which there are different grouping methodologies. In this case, taking the Euclidian quadratic distance as proximity measure, the classification method used is the ascending hierarchy type, namely through Ward's method (minimal loss of inertia). This method of Ward implies a strategy of union of individuals in cluster through a hierarchical procedure, in which in each stage of agglomeration two individuals are united for which there are minimal differences with respect to the centroid of the Cluster, that is to say that it is looked for through this method that the conglomerates are constituted in such a way that, when melting or joining two individuals, the loss of information product of this fusion was minimal. As expressed by Ward (1963, p. 236)

\footnotetext{
"Situations often arise in which it is desirable to cluster large numbers of objects, symbols, or persons into smaller numbers of mutually exclusive groups, each having members that are as much alike as possible. Grouping in this manner makes it easier to consider and understand relations in large collections; hence it often increases efficiency of management. Grouping, however, ordinarily results in some loss of information that may be quantified in a "value-reflecting" number"
}

The districts were then classified in the most appropriate number by evaluating the coefficients in the agglomeration table. Based on the values obtained and on the evaluation of the coefficients, 4 clusters or type of municipalities are chosen according to their general initiative and their initiative to 
fight against poverty. Once the classification has been done, each of the agglomerations is interpreted through the explicative variables included in the two-entry table below, where the respond frequency of both variables is laid out (Table 5). Annex 3 presents the graph that emerged from this cluster analysis. This type of municipality category is described below:

\subsection{Type 1: Promotion of development and urban local assistance}

The distinctive characteristic of these 49 municipalities is that they act promoting productive investment and development, seeking improvements in the road network and territorial structuring. These are investments in infrastructure and regulation of the built-on areas and settlements, as well as traffic regulation. The municipality has autonomy in the fight against poverty, which means that it has its own citizen assistance initiatives through the provision of services and goods to impoverished families, ranging from the provision of services and ordinary communal goods to the provision of family emergency funds, such as deaths or situations of sudden impoverishment due to health-related expenses. The municipalities do not depend on the intermediation or execution of these activities from the Central nor Departmental Governments as they do with conditioned assistance activities (Tekoporâ - Senior Citizens - food assistance for impoverished senior citizens). This are usually prosperous communities who are better organized and have a more consolidated governance as well as fewer requests for extreme poverty assistance.

These municipalities have a greater average population than the national average with 47,218 inhabitants per commune as opposed to the national average of 27,418 . They also have a higher population growth rate with $1.6 \%$ yearly opposed to the national average of $1.4 \%$. These zones are highly receptive of population. They also have a lower UBN rate (Unsatisfied Basic Need) ${ }^{1}$ with $51 \%$ of homes showing as least one UBN against the national average of $55 \%$.

Some of these are San Bernardino, San Cosme y Damián, Caaguazú, San Juan Bautista, Capiatá, Itaguá, Lambaré, San Lorenzo. The paradigm of this type of municipality is the Capital, Asunción, which has a Social Development Office, municipal schools, assistance to toddlers and youths, responders to climatic events (flooding), etc.

\subsection{Type 2: Network management and rural development}

The distinctive characteristic of these 40 municipalities is that they focus their initiatives on the construction of layered politic-institutional networks (local, departmental, national and international) which allows them to obtain resources and assistance for development.

These municipalities lean on national institutions to underpin or foster productive promoting networks since they are farming, cattle breeding or industrial municipalities where the private enterprise functions without state support. That means that the productive fostering is in the hands of local companies and other players of the territory. Expanding higher education, the road network,

\footnotetext{
${ }^{1} \mathrm{UBN}$ is not a problem solely of the homes but of the existent state coverage since there are some prosperous rural zones which nonetheless possess remote schooling and health services or lack sewerage or shared drinkable water. The general coverage of these needs is limited by their high cost, which results in higher UBN figures than those found in denser urban zones which can provide these services for a lower cost.
} 
and the logistics are key issues in these territories. Thus, within this context, the mayors consider themselves to be articulators and promoters of their territories with other organisms and political or commercial players. On the other hand, the reduction of poverty initiatives are not autonomous nor originate locally, but are centralized in utilizing resources which come from other networks and players, which are conditioned transfers and Central government programs fostering agriculture.

These municipalities have greater populations that the national average, with 36,643 inhabitants, and a strong yearly populational growth rate (1.6\%). The UBN are somewhat inferior to the national average with $53 \%$ of homes having at least one UBN.

Some of these municipalities are Concepcion, in the North, Villarica, at the center of the Eastern Region, and Loma Plata, in the Chaco, which has a successful commune comprised mostly of Mennonites. Some other municipalities in this group have predominantly immigrant populations from Brazil (known as Brasiguayos) such as Santa Rita, Ciudad del Este's successful satellite municipality, Minga Guazu, and Fram which has a Slavic population. This is not a homogenous group, nor do these municipalities have the same history since, on the one hand, there are new municipalities which have seen recent immigration (born towards the late XX century), such as Loma Plata or Fram, and, on the other, the centennial municipalities such as Concepcion or Villarica which after lagging behind in they development dynamics have made efforts to catch up in the last decades by betting on their social and symbolic capital.

\subsection{Type 3: Infrastructure, human and social capital}

These are 40 municipalities which stand out for having a more economic and business-like vision of territorial development, reason for which they promote productive development and create infrastructure as a productive economic competitive factor. An element which characterizes these municipalities is that the reduction of poverty does not rely on classic social assistance, own or from the national government, but by the social and human capital formation initiatives, focused on education and provision of basic services. Thus, the reduction of poverty is understood as a policy of economic promotion.

Among these municipalities are Ciudad de Este, Pedro Juan Caballero, Ayolas, and Filadelfia. The paradigm over which these municipalities are sustained is corporate modernity, generation of wealth, reliance on the market, and dynamics of capital. These are zones with very influential corporations and, in some cases, exclusive. They are usually located in zones with an agro-exporter or energy production economy; they also include cities with greater demographic growth such as Luque, Guarambaré, or Augusto Saldivar where, along with business growth, there is an accelerated urbanization process and a shift from the family farm culture to the internal urban market (fruticulture, horticulture, and minor livestock).

In general terms, these municipalities have lower population than the national average, with 21,336 inhabitants on average but with a strong dynamic of population growth (1.7\% yearly) and with severe problems of isolation, with 57\% of homes having some UBN. The most vulnerable ones are the indigenous population, the Criollo farmers, and the new immigrants who are settling in areas with underdevelopment infrastructure. 


\subsection{Type 4: Economic competitivity and rural development}

This is the largest group with 121 municipalities. Even though it may seem as a multiple and heterogenous group of municipalities, when analyzed in detail it should be considered as the most representative of the tension between a traditional model, and a model that promotes the municipalities. The group is comprised of municipalities located in territories where a duality between a commercial society and a traditional family society is manifested. A great challenge for these municipalities arises from this: achieving an increase of competitivity and productive development, and of employment, which guarantees social cohesion.

Not all of them have as a manifest structural objective to increase economic competitivity and employment, objective for which they generate multiple and varied initiatives to promote investment, productive development, and improving the roads network which limits productive development and cultural connectivity. On the other hand, the initiatives to reduce poverty do not depend on their resources but are rather limited to focusing the national government's resources, to organizing the local demand for social plans (Tekoporâ) and to support agricultural production in the most impoverished rural sectors. This means that the initiatives to reduce poverty are not part of the Municipality's autonomous scheme, but rather of the National Government through its different ministries.

These are smaller and more numerous communes, with 18,361 inhabitants on average and with the lowest rate of population growth (1.2\% yearly). Even if the rural population has a lower growth rate than the urban dynamics, its decrease is lessened by strong rural culture and tradition which is partly maintained and partly modernized due to the development of community and transport. On the other hand, the UBN of these municipalities are higher than the average at 57\%.

The paradigms of these municipalities are Encarnación, with its contrast between its wealthy and impoverished zones, Piribebuy and Caacupé, lying somewhere between the traditional society and business expansion, Curuguaty, where the frontier of productive models generated strong tensions, and Paraguarí, a modernizing conservative society which is struggling with integration, etc.

Faced with this type of actions carried out by the different types of municipalities, the National Government or the departmental governments remain inert, that is to say, they support all possible initiatives, but they do not have any type of clear or premeditated policy for orienting the actions, that is to say that each type of municipality advances in possible actions, without a clear definition of what is the horizon to follow or the best possible strategies to promote development and reduce poverty. It could be affirmed without a doubt that this category of municipalities, and each of the types of municipalities are ultimately a sample of the structural incapacity of the national government to lead the process of territorial development in the country, leaving all of them to advance by trial and error.

The following table (Table 5) gives an account of each of these types of municipalities. It presents each of the agglomerations with its two large variables and the subcategories that come from the survey responses and that have been systematized. The table presents the frequencies of the responses of the two variables. 


\section{TABLE 5 TYPES OF MUNICIPALITIES ACCORDING TO THEIR GENERAL INITIATIVE AND THEIR INITIATIVE TO FIGHT AGAINST POVERTY}

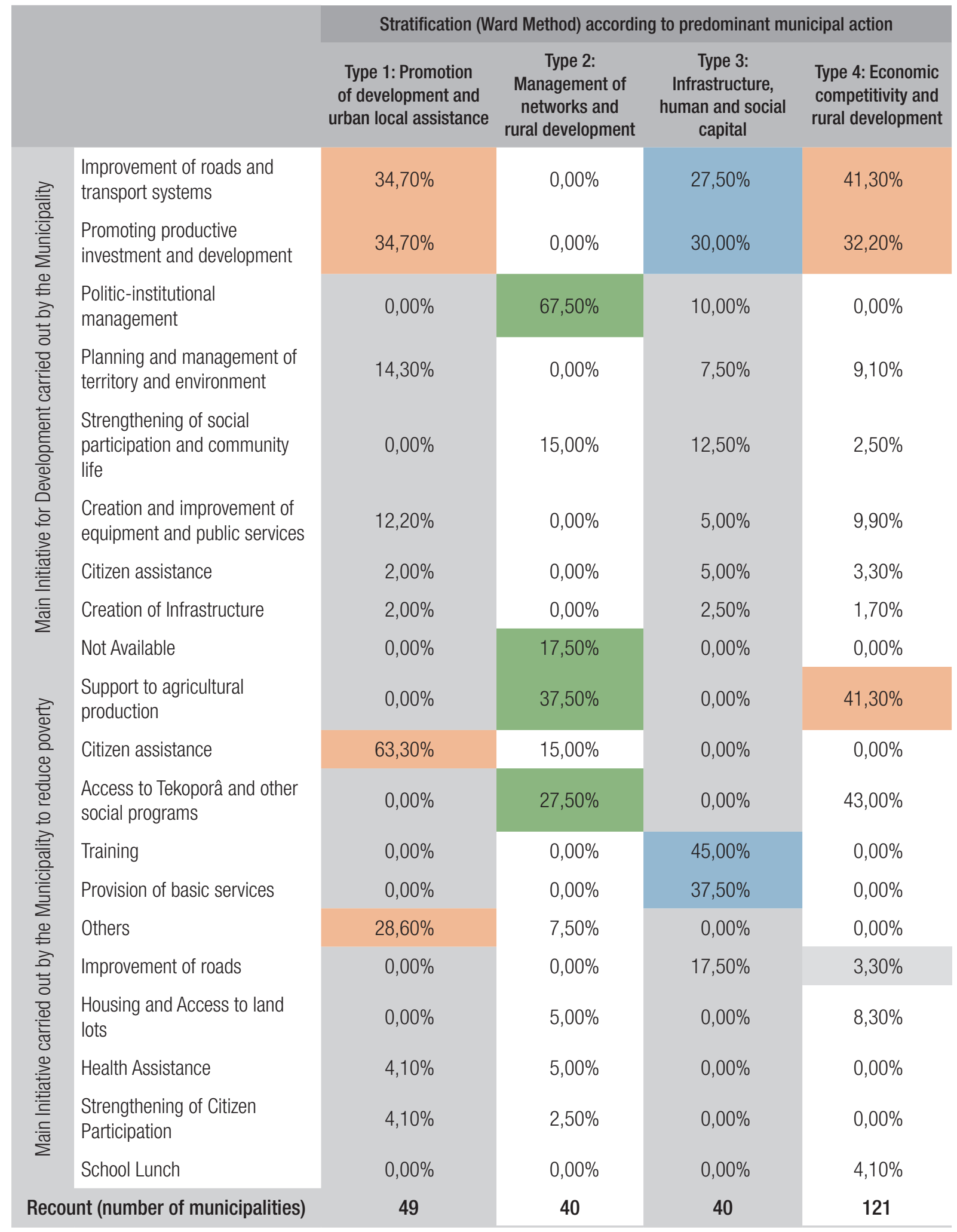

Source: Elaborated by the author based on the processing of information from the Local Development Management Survey (2016). 


\section{CONCLUSION}

Territorial development is a complex combination of the public action, the private actions, and the collective action (or civil society) built within the territorial context, marked in the Paraguayan case by the processes of territorial transformation, demography changes, strong productive transformation linked to the opening to foreign markets, and growth of the rural enterprise. This combination of actions can give way to outstanding development dynamics capable of contributing to overcoming poverty, improving quality of life, economic competitivity, creation of sustainable jobs, and a considerable improvement of environmental and habitat conditions.

In Paraguay, as in other Latin American countries, these dynamics are strongly conditioned by the role and presence of the State in its different levels, in central, subnational, and local governments. Much has been analyzed and written in Latin America concerning the role local governments and the decentralization processes play in relation to development, especially during the 90 s which was a period of heavy structural adjustments of in the region and central government delegated responsibilities to the local government (Aghón \& Cortes, 1998). This research aims to complete the existent literature, placing emphasis in analyzing the actions set in motion by the Municipalities starring from the hypothesis that they have a key and structuring role in the territorial development of a country even if they do not all share the same logic of function and of action concerning development. Various elements can be observed from this work.

First, the existent difference between the municipalities in terms of surface, population and productive systems, and the discourse of the mayors and their municipal teams reflect three ideas or symbolic agreements concerning the current state of the municipalities sin Paraguay:

- The first of these representations is that poverty is the main problem the country and the municipalities face. The population is seen as poor, lacking means of support and work. It is seen through compassion or fear by those who have overcome those needs, or as an identity, nande poriahu (we the poor), by a pre-citizen mentality which seeks to get closer to the better-off and who understands that poverty is a source of rights.

- The second representation is that nature is in part inaccessible (no roads nor infrastructure), an unwelcoming territory, unapt for work, not very accessible for the market, and hard to share as a community due to lack of transport routes which would allow for people to overcome the distances as to live and work together. Behind this outlook is the idea that nature is a hostile adversary or that it limits coexistence, an uncultivated environment encroaching on the populated niches. A neocolonial tradition of the conquistador which bent the land and its people. The pre-Columbian vision of the indigenous people interpreted nature and space as an area populated by spirts, animist, a space to hunt and gather. This space changed to a capitalist extractive model exploited by a few players clearly linked to transnational corporations.

- The third representation is that there is an insufficiency of State and of public services. There it a clear failure by the state institution to meet the collective interest and to provide solutions to common needs, whether it be due to lacking the means and low collection, to the lack of a more inclusive social contract, or the private capture of collective resources. 
Second, it is based on these representations concerning the country and municipalities' situation that the mayors and their technical teams generate actions to overcome the issues under a development ideal which changes based on geographical and cultural contexts. The actions set in motion are clearly concordant with the perceived problems.

Third, Municipalities can be classified based on the behavior they have when facing their problems. This means that the municipalities can be differentiated and classified according to their styles of intervention or the type of actions set in motion to revert the structural problems and build territorial development processes based on their options and means. Although this typology constitutes a summary of complex dynamics, it involves two big structural dynamics of the municipalities.

- The network creation and resource capture dynamic are observed along general lines in to clearly opposing situations. On the one hand are the municipalities which build a multilayered network to capture resources, and on the other the municipalities with low capacity to manage networks, which is why it's focused on endogenous resources.

- The dynamic of the actions themselves where the municipalities aimed at creating infrastructure and equipment, those aimed at the promotion of productive development, those aimed to citizen assistance in any of its manners, and even those municipalities whose actions are quite diversified can be clearly seen. The relative weight of urban and rural modernity matter here, as do the inertias, relations, and traditions.

This typology of municipalities according to their style of action synthesizes a vast field of possibilities for their intervention, which is why this typology has to be considered first and foremost as a tool for the interpretation of the way to "build" local development, as well as of intervening when facing reality. It is not about a description of the structural characteristics of how the municipalities are towards their population, surface, budget, etc.

In the future, new works of analysis could analyze the real and measurable impact each of these types of municipalities have in the territorial development dynamic of the country, as well as lessening social problems in order to establish institutional strengthening and promotion of development criteria better adjusted to the style and vocation of the municipalities and their conditions. 


\section{REFERENCES}

Aghón, G., \& Cortés, P. (1998). Descentralización y gobiernos municipales en América Latina. In R. Jordan, \& D. Simioni. (Comp.), Ciudades intermedias de América Latina y el Caribe: propuestas para la gestión urbana (pp. 69-106). Vitacura, Santiago de Chile: Comisión Económica para América Latina y el Caribe.

Bustos Cara, R. (2008, mayo). Por una geografía de la acción territorial. In Anales de las 100 Jornadas Cuyanas de Geografía: La geografía frente a la necesidad de integrar territorios y voluntades, Mendoza, Argentina.

Cabello, C., \& Vázquez Aranda, V. I. (2013). Propuestas para un sector productivo competitivo e inclusivo: un instrumento de diálogo y construcción de consensos para el desarrollo rural integral. Asunción, Paraguay: Instituto Desarrollo.

Cámara Paraguaya de Exportadores y Comercializadores de Cereales y Oleaginosas. (2013). Área de siembra, producción y rendimiento. Asunción, Paraguay. Retrieved from http:// capeco.org.py/area-de-siembra-produccion-yrendimiento/

Crozier, M., \& Friedberg, E. (1977). Lacteur et le système: les contraites de l'action colective. Paris, Francia: Points.

De Rubertis, S. (2010). Sviluppo come conflitto. La pianificazione strategica in Puglia. Lecce, Italia: Università del Salento - Coordinamento SIBA.

Dirección General de Estadísticas, Encuestas y Censos. (2015). Población nacional estimada y proyectada, según sexo, departamento, y distrito, 20002025: revisión 2015. Asunción, Paraguay. Retrieved from https://www.dgeec.gov.py/Publicaciones/ Biblioteca/proyeccion\%20nacional/Proyecciones $\% 20$ Departamentales\%20-\%20final.pdf

Giménez, C. (2009). Situación y perspectivas del sector agro-rural paraguayo. (Serie Sector AgroRural Paraguayo no 3). Asunción, Paraguay: Instituto Interamericano de Cooperación para la Agricultura. Retrieved from http://repiica.iica.int/docs/B2014e/ B2014e.pdf

Guereña, A. (2011). Derecho a producir. Invertir más y mejor en la pequeña agricultura de América del Sur. Barcelona, España: Intermón Oxfam.
Retrieved from https://www-cdn.oxfam.org/ s3fs-public/file_attachments/derechoaproducir_ oxfamcrece-04102011_3.pdf

Lajarge, R. (2011). Le développement territorial ou comment satisfaire le besoin grandissant de territorialités multiples. Paris, Francia: Fonder les Sciences Territoriales. Retrieved from https://halshs. archives-ouvertes.fr/halshs-00700675/document

Manzanal, M., \& Ponce, M. (Org). (2012). La desigualdad ¿del desarrollo? Controversias y disyuntivas del desarrollo rural en el Norte argentino. Buenos Aires, Argentina: Ediciones Ciccus.

Nickson, A., (2016). El gobierno local en el Paraguay, un análisis comparativo a través de diez elementos. Asunción, Paraguay: Investigación para el desarrollo \& Asociación de Juntas Municipales.

Oosterbeek, L. (2012, diciembre). Desafios ambientais e culturais em contexto de crise: uma perspectiva de Gestão Integrada do Território. In Anais do Congresso Luso-Brasileiro de Interfaces multidisciplinares do Direito para a Gestão Integrada do Território, Mação, Portugal.

Programa de las Naciones Unidas para el Desarrollo. (2010). Sector rural paraguayo: una visión general para un diálogo informado. Asunción, Paraguay: Author.

Riquelme, Q., \& Vera, E. (2013). La otra cara de la soja. El impacto del agronegocio en la agricultura campesina y en la producción de alimentos. Asunción, Paraguay: Oxfam.

Rojas Villagra, L. (2009). Actores del agro-negocio en Paraguay. Asunción, Paraguay: Diakonia - BASE-IS.

Sili, M. E. (2018). La acción territorial: una propuesta conceptual y metodológica para su análisis. Revista Brasilera de estudios Urbanos regionals, 20(1), 11-31.

Truda, G. (2008). The Dynamics of a Territory: the Main Actors of Sustainable Development in the Irno Valley. Huelva, España. Retrieved from https:// halshs.archives-ouvertes.fr/halshs-00523759/ document

Vanier, M. (2015). Demain les territoires. Capitalisme reticulaire et espace politique. Paris, Francia: Hermannn.

Vázquez, F. (2013). Ciudades intermedias y sustentabilidad urbana en Paraguay. In F. Dane 
(Ed.), El Desafío del desarrollo sustentable en América Latina. (pp. 223-243). Rio de Janeiro, RJ: Konrad Adenauer Stifung.

Vázquez, F., \& Goetz, K. (2013). Atlas de Políticas Públicas del Paraguay: tendencias y retos de intervención. Asunción, Paraguay: Ministerio de Hacienda.

Verdecchia, M. (2007, October). Modernización agraria en Paraguay. In Anales del Encuentro
Regional del Programa Mercosur Social y Solidario (PMSS), Asunción, Paraguay.

Victory, C. (1999, October). Gobiernos municipales y desarrollo local en Iberoamérica. Revista CIDOB d'afers Internationals, (47), 36.

Ward, J. H. (1963, March). Hierarchical Grouping to Optimize an Objective Function. Journal of the American Statistical Association, (58), 236-244.

\section{Marcelo Sili}

https://orcid.org/0000-0002-8666-0661

Doctor in Rural Studies from the Université Toulouse Le Mirail; Scientific Researcher of CONICET (Argentina); Director of the ADETER Center and Associate Professor of the Department of Geography and Tourism, Universidad Nacional del Sur. E-mail: sili.marcelo@gmail.com 


\section{ANNEXES}

\section{ANNEX 1: SURVEY GUIDE FOR THE ANALYSIS OF TERRITORIAL ACTION}

\section{Municipal characterization}

1. Population of the District

2. What is the demographic dynamics of the District? (growing, stable, population decreasing)

3. What are the predominant agricultural activities in your District?

4. District NBI Level

5. What is the state of infrastructure and services?

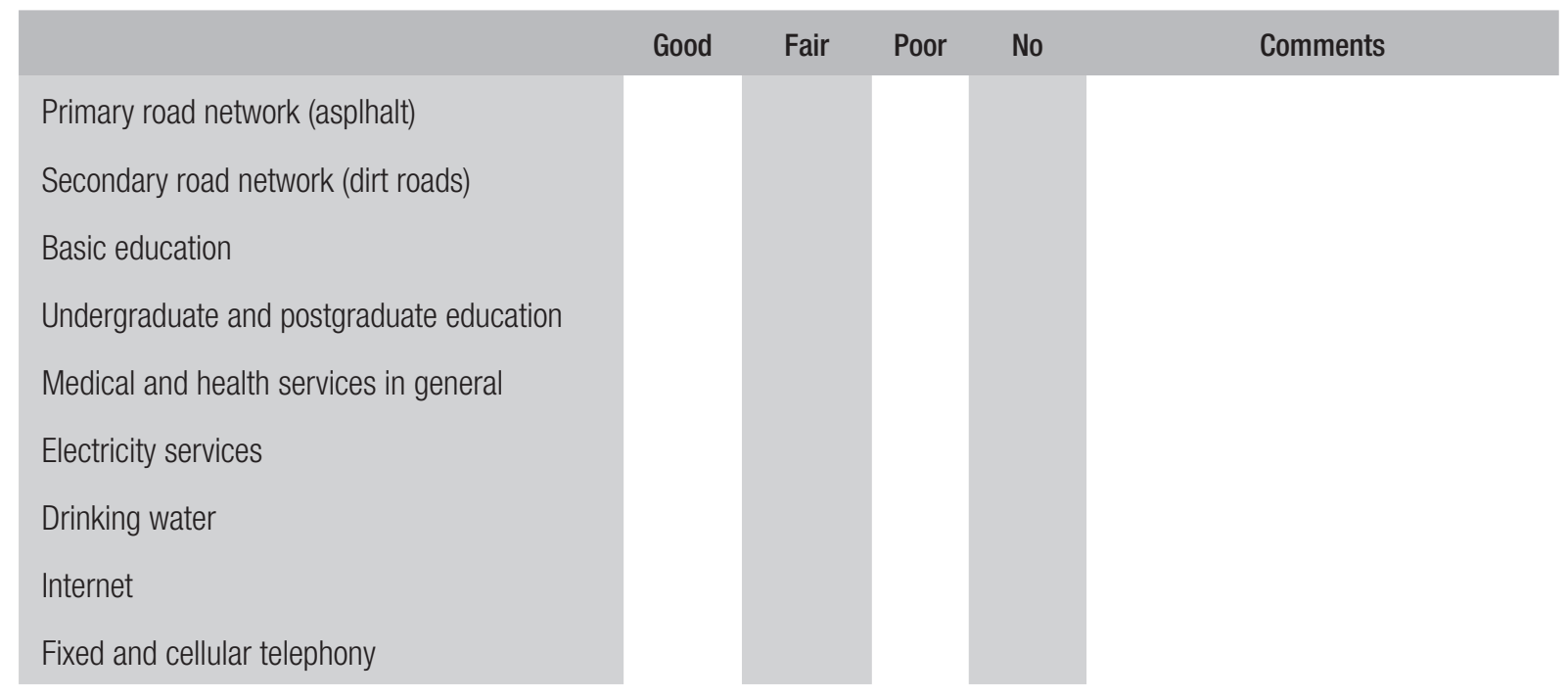

6. What are the main problems of the district? (list at least 5 in hierarchical order)

\section{Municipal management}

7. What is the profession of the Intendant?

8. What administrative areas does the Municipality have?

9. What is the level of training of officials?

10. What is the level of training of the personnel?

11. What is the amount of the annual budget?

12. What are the main problems of municipal management?

13. What are the main strengthening needs for municipal management?

\section{Actions and development management}

14. What are the main initiatives carried out in the District to generate developmental dynamics (mention at least 5 in hierarchical order)? 
15. Which actors participate in these initiatives in order to generate a greater development dynamic? 16. What are the main actions taken in the District to reduce poverty? (list at least 5 in hierarchical order)

17. Which actors are involved in these poverty reduction initiatives?

18. What inhibits or limits these initiatives (lack of resources, lack of technicians, lack of interest and consensus on the part of the population)?

19. Do these actions form part of a comprehensive development plan?

20. Are these actions linked to other local actions or are they done alone? (Convergence, fragmentation and lack of coordination of initiatives)

21. What are the main needs for strengthening development management?

\section{ANNEX 2: TYPE OF RESPONSE TO KEY QUESTIONS 6, 14 AND 16}

Question 6: What are the main problems of the district? (example of responses already categorized)

- Degradation of habitat and environment

- Lack and deterioration of public equipment and services

- Lack of roads

- Lack of basic infrastructure

- Low level of development of family farming

- Weakness of Municipalities

- Poverty, unemployment and social disintegration

- Violence and insecurity

Question 14: What are the main initiatives carried out in the District to generate development dynamics (example of responses already categorized)?

- Assistance to citizens (provision of subsidies for travel to the capital, subsidies for payment of funeral expenses, delivery of construction materials, delivery of food, etc.).

- Promotion for investment and productive development (delivery of seeds, tilling of small farmers' land, coordination with private companies for management, etc.).

- Territorial and environmental planning and management (local development plan, environmental improvement plan for a stream or special area, zoning of urban areas, etc.).

- Improvement of roads and transport systems (paving or graveling of roads, passage of road machinery for maintenance of the rural road, etc.).

- Creation and improvement of public facilities (improvement of medical rooms or schools, creation of a municipal hall, etc.).

- Creation of infrastructure (creation of sewerage, creation of drinking water network).

Question 16: What are the main actions taken in the District to reduce poverty (example of responses already categorized)?

- General training for the poorest and most vulnerable population on health and production issues.

- Provision of basic services (water, electricity). 
- Road improvement (consolidated roads in peri-urban and rural settlements).

- Housing construction and access to land (financial assistance for housing construction or land purchase).

- Access to tekopora and other social plans (subsidies or universal income for vulnerable families)

- School Lunch (school lunch for students from low-income families).

- Support for agricultural production (support with seeds, tillage of land, delivery of tools).

- Health care.

\section{ANNEX 3: CLUSTER CHART}

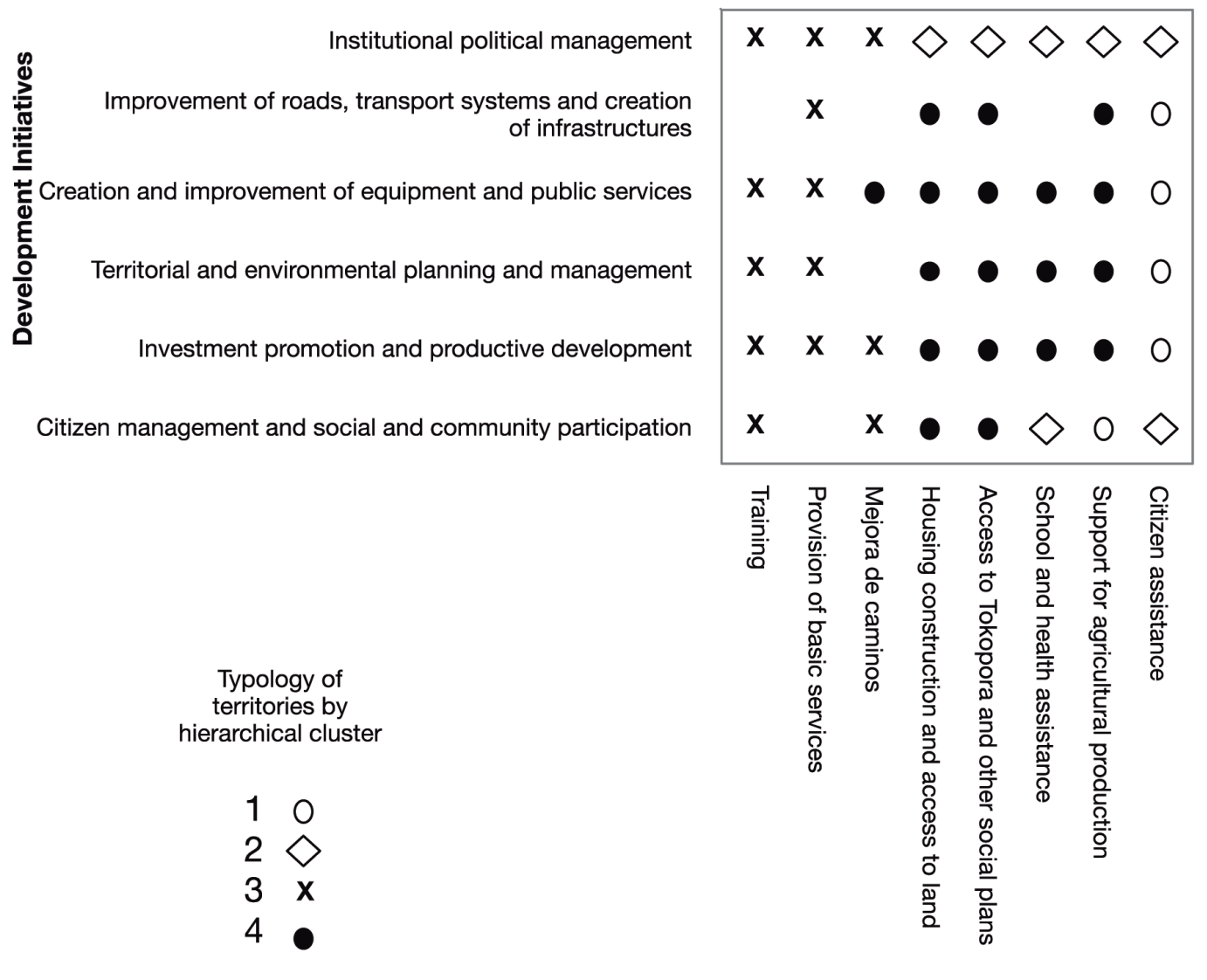

Poverty Reduction Initiatives

Source: Elaborated by the author based on cluster processing. 